\title{
Trends of Patriotic Education in Modern Russian Higher Education
}

\author{
Dmitry Yu. Narkhov ${ }^{1, *}$, Elena N. Narkhova ${ }^{1,2}$, Vlas P. Repin ${ }^{2}$ \\ ${ }^{1}$ Department of Organizing Youth Work, Ural Federal University named after B.N.Yeltsin, \\ Ekaterinburg, Russia \\ ${ }^{2}$ Department of the theory, methodology and legal support of the public and municipal administration, \\ Ural Federal University named after B.N.Yeltsin, Ekaterinburg, Russia \\ ${ }^{*}$ Corresponding author
}

Keywords: Higher Education, Patriotic Education, Students, State Youth Policy, Self-Realization.

Abstract: They studied changes in patriotic education of Russian students in the post-Soviet period. The study was aimed to find ways of effective interaction between the state and students. The theoretical basis of the article is an interdisciplinary approach and the data of all-Russian sociological surveys. The attention is drawn to the paradoxical situation in the social Institute of higher education - the gap between the functions of translation of professional knowledge and reproduction of culture, education of professional and citizen. They develop the idea of positive social initiative of students as the basis of modern patriotic education. Grant support of significant social initiatives is studied as a new form of social interaction of the state and students. Russian students show positive dynamics of their understanding of patriotism as positive social activity. They give prove for the necessity and possibility of developing a unified approach to the implementation of civil and patriotic education of students in Russian universities.

\section{Introduction}

One of the basic functions of the institution of education as a translator of culture is patriotic education of youth. This function gives the possibility of bringing together the interests of society and the state and to form the civic position of young people on this basis. This is particularly important for students - the future elite of the country. The study of the nature of the implementation of this function allows us to see, on the one hand, how the state creates conditions for the socio-cultural development of its citizens, and on the other hand, if students are ready to actualize themselves professionally and socially in their country. In Russia, during the era of social transformations in the context of globalization and active development of the knowledge society, the problem of patriotic education of students becomes very important and difficult at the national level as well as at the regional level. The dynamics of social processes in higher education actualizes the task of monitoring the patriotic sentiments of students and following the ways of realization of their social activity. 


\section{Methodology and Methods of Research}

The theoretical base consists of the ideas of leading scientists about the multidimensionality of youth and students. We used the system, institutional, resource and risk approaches during this study [1; 2, Chapter 1]. The preparation of the article was based on the analysis of Federal and regional legislation, domestic sociological literature on patriotic education [3], the results of mass regional and Federal sociological surveys conducted with the direct participation of the authors [4], protest potential of students [5].

\section{Discussion and Results}

The system of patriotic education of the young generation during the Soviet period was distinguished not only by ideological conceptualization, but also by a clearly built system of its implementation in the educational system. The developed ideology system of educational work started in school and was continued in higher professional education. A vertical organizational structure was the basis for the implementation of this type of education: Administration - the party Committee - the Komsomol. Patriotic education of Soviet students took into account the areas of training and the interests of students in part. The confrontation between the two world systems (capitalist and Soviet), the most severe consequences of the World War II for the USSR (the death of more than 26.6 million people $-10 \%$ of the country's population at that time, almost complete destruction of industry, agriculture, cultural values of the European part of the country - material losses up to $30 \%$ of national wealth [6] determined the main form of patriotic work with young people for a long period of time - military-Patriotic. First of all, it was focused on the readiness of young people to defend the state and remember the lessons of the World War II. At the same time, the patriotic work concerned the labor, physical training of young people and students, their creative activity and leisure, and so on. It corresponded to the general political guiding line and were leaded by party and state administration. A single ideological platform, combined with numerous directions of its implementation, ensured the sustainability and functioning of all social institutions in society and the society itself. This model of patriotic education becomes more attractive for some modern Russian politicians due to its high effectiveness.

The mainl humanistic idea of the democratization of the USSR at the end of the XX century was to stop the civilizational confrontation "East - West", understanding the integrity and fragility of the world. The period of social transformations of the Russian society in the 90s and early 2000s was based on a change of the ideological paradigm, and appeared in the rejection of the Communist party ideology, but proceeded along with a severe economic crisis, the redistribution of property and spheres of social influence by new elites, the rapid development of mass consumption society (the famous "be to have" - E. Fromm) and led to the abandonment of the patriotic education system, even in higher education. Due to healthy conservatism, the preservation of patriotism in society was carried out as a natural process. Family, school, professional community - the main social institutions where the patriotic feeling develops simultaneously with the process of socialization - to some extent, brought up the patriotic feelings fragmentary. But proper patriotic education as a purposeful activity which was carried out systematically by state and non-state political and social subjects, was lost.

The transformation of the functions of patriotic education in school to the dysfunctions caused many problems by the early 2000s, which are not solved till now. And one of them is the crisis of youth identity (including students) - subcultural, professional, national. The Russian society has developed steady trends to export different types of capital - economic, cultural, social. A serious problem that proves the need of focusing on patriotism is migration processes, the desire of young people to realize their professional and life strategies out of their region and country, "brain drain"as it is called in political slang. 
Patriotic education respond to internal and external challenges, and becomes prior for domestic policy and a guarantee of national and state security. Obviously, there is a need to solve the most acute problems of formation of patriotic education system at the state level as a basis for the consolidation of society and the state. In this regard the public order was focused on the development of high social activity in Russia, civic responsibility, spirituality, the formation of citizens with positive values and qualities, who are able to show them in the creative process in the interests of the motherland [7]. At the same time, it is necessary to understand the essence of youth education in a new way, to see not only the object of education, but the subject of patriotic culture, emphasize the self-realization aspect of the formation of a young man - a patriot of his homeland.

Significant measures have been taken since 2001 to develop and strengthen the system of patriotic education of Russian youth. Three five-year state programs "Patriotic education of citizens of the Russian Federation" (the total amount of funding for 15 years-1452.95 million rubles) were consistently implemented at the federal level and the fourth continues to operate for the period 2015-2020 (by 1666.56 million rubles for 5 years). Regarding student youth, these programs are a direct investment into human capital, because one of the expected (and in many ways, as our measurements show, achievable) results is to improve the quality of work on patriotic education, professional orientation of young people, their involvement into various forms of governing (including civil and military service), self-realization in various spheres of the Russian industry and service, as well as in educational system, science, culture, sports and other social activities. The coordinator of this program is the Federal Agency for Youth Affairs (Rosmolodezh) and its subordinates - federal and regional centers of patriotic education, that are state budgetary institutions.

The paradox of the development of patriotic education of students is that the modernization of the education system during 2002-2016 resulted in changes of the approach to extracurricular activities in higher education. Russian universities, while recognizing in words its necessity and importance, still shifted their focus on the learning processes, the formation of narrow professional competencies, the commercialization of the educational process. Educational activities were excluded from the accreditation indicators of universities. In the social Institute of higher education there was a gap between its two most important functions: - translation of knowledge, professional training and translation of culture, socialization -education of professional and citizen. This is also applicable to the sphere of patriotic education. Nowadays, the extracurricular activity of students develops in the form of self-organization. On the one hand, numerous public organizations and non-commercial associations, patriotic clubs and military-patriotic centers, some business communities are the active subjects of patriotic education of youth. The most successful among them is the federal "Russian center for civil and patriotic education of children and youth", "Russian Youth Union", "Voluntary Society for Assistance to the Army, Aviation and Navy of Russia", NCO "Vympel", regional "Union of UrFU students", museum complex of military and civil equipment of the Ural mining and metallurgical company and others. On the other hand, the practice of eliminating the traditional position of Vice-rector for educational work in the Russian higher school with the transfer of their functions to the management of social work and the simultaneous reduction of activities and the volume of their funding becomes widespread.

Thus, the main activity on patriotic education is carried out at the level of subjects of the Russian Federation and is carried out by coordination of actions of Federal executive authorities, executive authorities of subjects of the Russian Federation, business communities, public and public professional organizations. The system of higher education is indirectly related to the implementation of patriotic education in modern Russia.

Despite this, students remain an active subject of patriotic activity. One of the new forms of activity in this direction is based on social self-organization of students and is implemented with the help of 
grant support of Federal Agency for Youth Affairs, which has been carried out since 2014 for all youth of the country, and, since 2018 - directly for the students (table 1).

Table 1. Grant Support of Youth Social Initiatives, 2014-2018 (Authors' Calculations Based on Data of the Federal Agency for Youth Affairs)

\begin{tabular}{lccccc}
\hline Indicator & 2014 & 2015 & 2016 & 2017 & 2018 \\
\hline The total amount of grants, million rubles. & 220 & 235 & 335.5 & 333.5 & 2537.17 \\
Number of nominations for individuals & 12 & 15 & 12 & 12 & 15 \\
Number of supported projects for individuals & 1251 & 789 & no data & no data & 2172 \\
Number of nominations for legal entities & 1 & 0 & 1 & 1 & 3 \\
Number of supported projects for legal entities & 12 & no data & $\begin{array}{c}\text { not less } \\
\text { than } 30\end{array}$ & not less & \\
than 30 & 60 \\
Number of supported projects in the nomination & $-*$ & - & - & - & 201 \\
"Youth groups" \\
$\begin{array}{l}\text { Number of supported projects in the nomination } \\
\text { "Youth projects of universities" }\end{array}$
\end{tabular}

Note: * The competition was not held.

Any youth group, organization or young person has the opportunity to offer their socially significant project for the grant competition in the appropriate category (like youth media space, entrepreneurship, science and creativity, physical culture and health, volunteering, etc.) and then implement it with the received funds. More than 700 experts-specialists from the sphere of state and corporate youth policy, scientific and pedagogical staff of colleges and universities, prominent political and public figures of the country, representatives of the sphere of culture and art, evaluate the projects which provides a high degree of objectivity of assessments and equal chances for participants of competitions. The size of grants varies from 100 to 300 thousand rubles for individuals and from 1 to 2 million rubles for NCOs and legal entities. According to data of 2018, the youth from all 85 regions of Russia took part in this activity. There were of 19837 of applications and 3825 youth initiatives were maintained. A public database consisting of several hundred successful practices of projects implementation was generated, and a significant number of them were created by students. For example, lets note the projects of A. Suvorova "Ecological cluster of Vladimir state University-the territory of youth initiatives"; E. Belyaeva, Primorsky Krai, Festival of technological art "Start-up"; A. Dotsieva, the Republic of Dagestan, "Limited possibilities, unlimited abilities".

1392,22 mln. rubles out of a total sum 3661,17 mln. rubles for the entire period, are spent on universities' youth projects of 2018. 311 universities received grants. You can find out about their implementation in a year or two. But there is no doubt that they will contribute to the successful self-realization of young people.

Sociological measurements of students' patriotic sentiments, made in recent years, show the effectiveness of existing patriotic programs in the country and the need for their further territorial and substantive expansion. According to the all-Russian survey (10 largest regions of Russia, $\mathrm{N}=3750$ ) [5], a group of students who definitely consider themselves patriots in 2018, that is 67\%, every tenth respondent could not answer the question: "do you think you are a patriot of Russia?" Every four out 
of five respondents gave a positive answer to the question "do you consider yourself a citizen of Russia (regardless the formal citizenship in the passport)", and the number of undecided was $6.8 \%$.

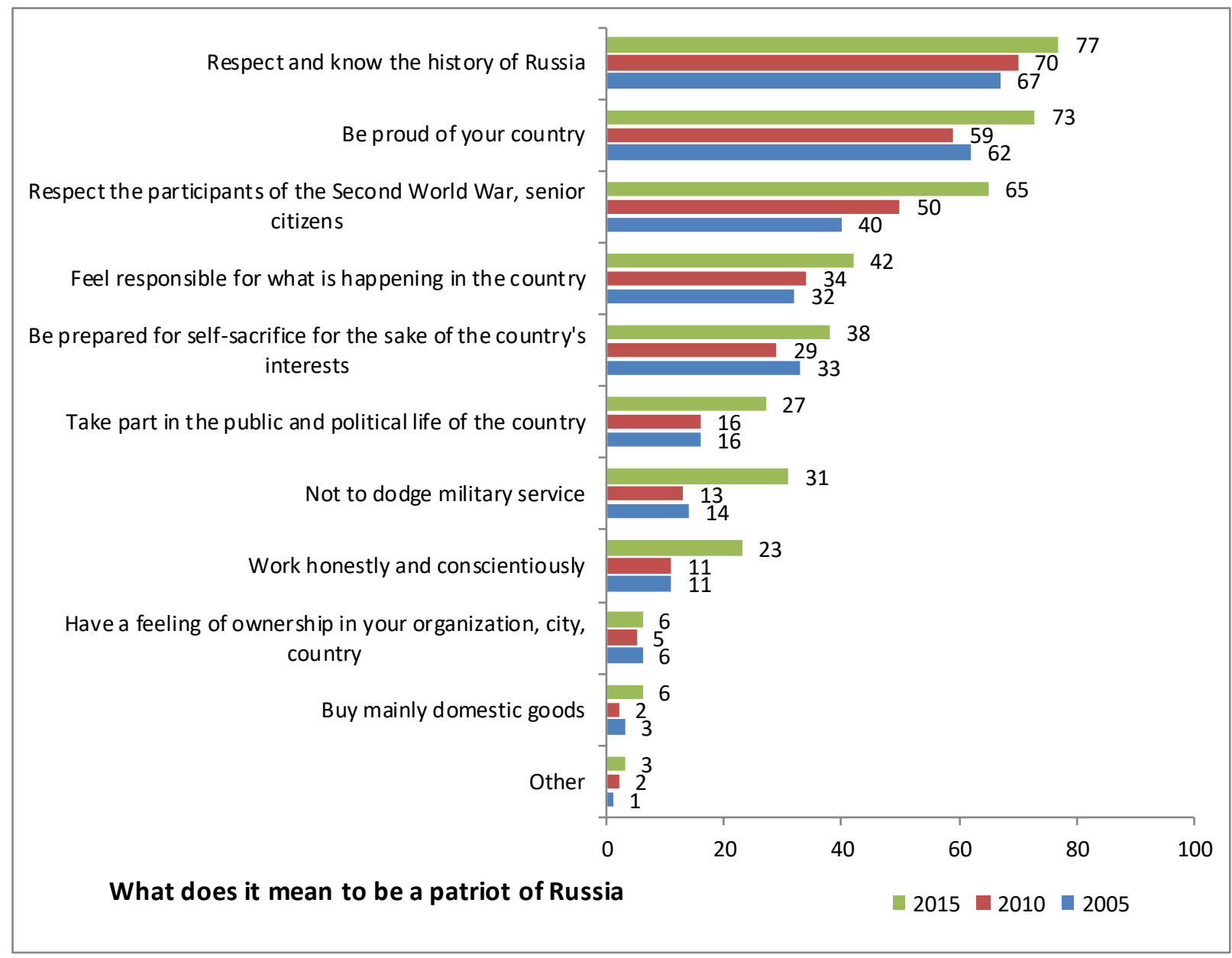

Figure 1. Students' Opinion about the Modern Patriot of Russia in 2010-2015, \% of the Number of Respondents. All-Russian Study, Representative Sample, $\mathrm{N}_{2005}=2000, \mathrm{~N}_{2010}=3500, \mathrm{~N}_{2015}=4750$. You can Choose Several Answers Simultaneously [4, p. 188].

It is obvious that modern youth patriotism is based on respect for the history of the country, pride for its success. There is obvious positive dynamics of students ' understanding of patriotism as a broad positive social activity (Fig. 1).

\section{Conclusions}

An important aspect of patriotism is its aspiration for the future. We have another approach to patriotism today. The most important thing in it is to form the desire of new generations to create their own future in their own country, at home, for their descendants and not to the detriment of anyone. The results of the analysis prove that administration of higher education organizations should be involved into the organization of patriotic work. The students remain active participants for the implementation of programs of patriotic education in terms of tactics. It remains a strategic cultural and professional resource of Russian society and its intellectual potential. The future of the country depends on where and how this resource will be implemented. The educational organizations have accumulated a lot of experience in the sphere of patriotic education, that allows to develop the 
concept of a unified approach to the implementation of civil and patriotic education of students, to provide it methodologically and methodically. This concept, which takes into account the essential, epistemological, regional, subcultural and other features of students, can be easily integrated into the educational process and contribute to the needs of self-realization of students, provide additional opportunities in the implementation of social initiatives within the state youth policy.

\section{References}

[1] Lukov Val. A. Theories of youth: cross-disciplinary analysis. Moscow, Canon publishing house; ROOI "Rehabilitation", 2012, 528 p. (In Russ.)

[2] Vishnevsky Yu.R. (gen. ed.), Bannikova L. N. [and others]. STUDENT of 1995-2016: dynamics of sociocultural development of students of Central Ural Mountains, Ekaterinburg: Yeltsin UrFU, 2017, 904 p. (In Russ.).

[3] Ayvazyan A. A. [and others], Vishnevsky Yu.R. (gen. ed.). Civil culture of youth of Sverdlovsk region: trends, problems. Ekaterinburg: Publishing house of Ural Federal University, 2017, 244 p. (In Russ.).

[4] Vishnevsky Yu. R. (gen. ed.). War was the day before yesterday ... The Russian students about the Great Patriotic War: monitoring materials "Modern Russian stu-dents about the Great Patriotic War". Ekaterinburg, Publishing house of Ural Federal University, 2015, 312 p. (In Russ.)

[5] Kozlov A. [And others]. Sociological analysis of protest behavior in the student's environment. In: Youth galaxy, 2018, No. 15, pp. 5 - 69. (In Russ.).

[6] Great Patriotic War of 1941-1945. In 12 volumes. Vol. 12. Results and lessons of war. - Moscow, Kuchkovo Pole publishing house, 2015, 864 pp. (In Russ.).

[7] Concept of patriotic education of citizens of the Russian Federation (2003). URL: http://xn--b1afa8admefdd2c.xn--p1ai/metod/008/001.htm (access: 01/20/2019) (In Russ.). 